AGRARIS: Journal of Agribusiness and Rural Development Research

Vol. 4 No. 1 J anuari -J uni 2018
IMAS WILDAN RAFIQAH ${ }^{1}$, DARSONO², J OKO SUTRISNO²

${ }^{1}$ Program Pascasarjana Agribisnis, Universitas Sebelas Maret, JI. Ir Sutami No. 36A, Surakarta ${ }^{2}$ Program Studi Agribisnis, Universitas Sebelas Maret, JI. Ir. Sutami No. 36A, Surakarta

Email korespondensi: imaswildan@gmail.com

\section{Daya Penyebaran dan Derajat Kepekaan Sektor Pertanian dalam Pembangunan Ekonomi di Provinsi Jawa Tengah}

https://doi.org/10.18196/agr.4160

\section{ABSTRACT}

This research aimed to analyze the power of dispersion and sensitivity of dispersion of the agricultural sector on the economic development of Central Java Province. This research used the data of Input and Output Table of Central Java in 2013. Data analysis method applied in this research is Input-Output analysis. The results showed that the agricultural sector represented by the livestock sector had 'above average' power of dispersion index of the overall index. Livestock sector was able to encourage the production growth in all sectors of the economy. On the other hand, the sensitivity of dispersion index of all agricultural sectors was lower than the average value of the overall index. This reflects the agricultural sector's low sensitivity to the changes of the external aspects which re- sults in the low forward linkage among the downstream sectors. In term of key sector identification, the agricultural sector as a whole was not classified in the priority sector I. How ever, the livestock subsector, representing the agricultural sector, was classified in the priority sector II on the economic development of Central Java Province.

Keywords: agricultural sector, economic development, power of dispersion index, sensitivity of dispersion index.

\section{INTISARI}

Penelitian ini bertujuan untuk menganalisis daya penyebaran dan derajat kepekaan sektor pertanian dalam pembangunan ekonomi Provinsi Jawa Tengah. Penelitian ini menggunakan data Tabel Input Output Jawa Tengah tahun 2013. M etode analisis data yang digunakan dalam penelitian ini adalah analisis Input-Output. Hasil penelitian menunjukkan bahwa sektor pertanian yang diwakili oleh sektor peternakan memiliki indeks daya penyebaran di atas rata-rata indeks keseluruhan. Sektor peternakan mampu memacu pertumbuhan produksi seluruh sektor perekonomian. Di sisi lain, nilai indeks derajat kepekaan seluruh sektor pertanian lebih rendah dari rata-rata indeks keseluruhan. Hal ini mencerminkan adanya kepekaan yang rendah terhadap perubahan aspek eksternal sehingga keterkaitan ke depan antar sektor hilir juga rendah. Sementara dalam penentuan sektor kunci, sektor pertanian secara keseluruhan tidak termasuk dalam sektor prioritas I. Akan tetapi subsektor peternakan berada pada sektor prioritas II dalam pembangunan ekonomi di Provinsi Jawa Tengah yang mewakili sektor pertanian. Kata kunci: indeks daya penyebaran, indeks derajat kepekaan, pembangunan ekonomi, sektor pertanian.

\section{PENDAHULUAN}

$\mathrm{H}$ al mendasar dalam pembangunan ekonomi daerah adalah mengelola potensi-potensi sumberdayayangada untuk menerapkan prinsip ekonomi dalam 
rangka mempercepat pertumbuhan ekonomi (Tarigan, 2012). Pembangunan ekonomi daerah melibatkan pemerintah dan masyarakat dalam mengelola sumberdaya yang tersedia untuk memacu perekonomian dan menciptakan kesempatan kerja baru (Arsyad, 2011). Bila dilihat secara holistik, potensi setiap daerah tidak sama antara satu daerah dengan daerah lain. Artinya dibutuhkan kebijakan kebijakan pemerintah daerah yang berbeda antara satu daerah dengan daerah lainnya yang mengacu pada potensi sumberdaya yang tersedia.

Sektor pertanian merupakan salah satu sumberdaya yang dimiliki Indonesia. Sektor pertanian termasuk dalam sektor yang berperan penting dalam pembangunan ekonomi nasional maupun daerah. Sektor pertanian menyumbang beberapa hal seperti penyediaan pangan, pemenuhan produk bagi industri sekunder dan tersier, tambahan devisa dan meningkatkan pendapatan di pedesaan sehingga memperbaiki kesejahteraan masyarakat pedesaan (Jhingan, 2010). Kontribusi sektor pertanian dapat dilihat dalam nilai tambah yang dicerminkan melalui PDRB dan penyerapan tenaga kerja.

Kontribusi sektor pertanian terhadap PD RB berada pada peringkat ketiga setelah sektor industri pengolahan dan sektor perdagangan (BPS, 2017). H al ini dikarenakan sektor pertanian cenderung mengalami penurunan dari tahun ke tahun. Begitu pula dengan kontribusi sektor pertanian di Provinsi Jawa Tengah, PD RB sektor ini cenderungmengalami penurunan dari tahun 2011 sampai tahun 2016 (G ambar 1). Pada tahun 2011, kontribusi PDRB sektor pertanian sebesar $15,75 \%$, lima tahun kemudian turun menjadi $13,68 \%$. Pada rentangwaktu tersebut, peningkatan kontribusi PD RB sektor pertanian hanya terjadi pada tahun 2015.

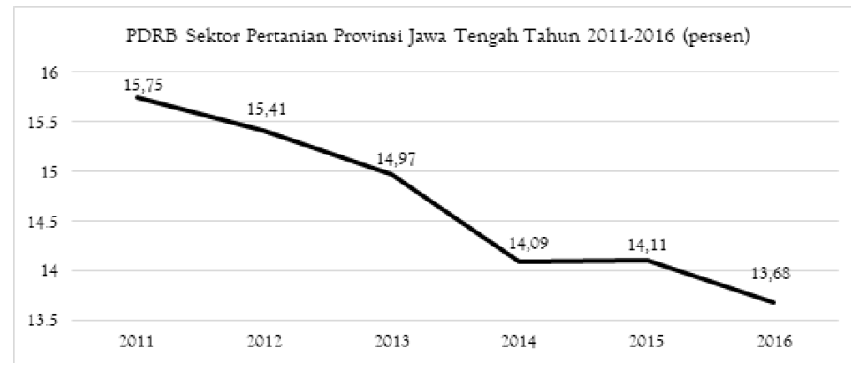

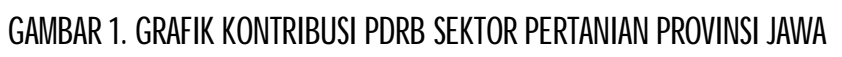

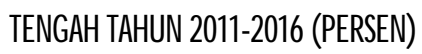

Walaupun kontribusi PD RB sektor pertanian tidak lagi besar, sektor pertanian Provinsi Jawa Tengah berada pada peringkat teratas dalam penyerapan tenaga kerja. Sektor pertanian merupakan kontributor terbesar dalam penyediaan lapangan kerja (Izuchukwu, 2011). Namun dari tahun ke tahun, jumlah tenaga kerja pada sektor pertanian di Provinsi Jawa Tengah semakin menurun. Pada tahun 2011, persentase tenaga kerja pada sektor pertanian di Provinsi Jawa Tengah sebanyak 34,5\% menurun menjadi 30,7\% pada tahun 2016 (BPS, 2017). W alaupun jumlah tenaga kerja sektor pertanian di Provinsi Jawa Tengah semakin menurun, alokasi tenaga kerja terbanyak tetap dipegang oleh sektor pertanian. $\mathrm{Hal}$ ini menunjukkan bahwa sektor pertanian masih menjadi penopang kehidupan bagi sebagian besar masyarakat di Provinsi Jawa Tengah.

Banyaknya ten aga kerja yang bekerja pada sektor pertanian membuat sektor tersebutmenjadi perhatian khusus. Terlebih, sektor pertanian erat kaitannya dengan kemiskinan karena sektor ini umumnya berada di pedesaan (Todaro, 2006; Cuong, 2010); Kuncoro, 2010; Dariah \& Sundaya, 2012; O morogiuwa, Zivkovic, \& Ademoh, 2014); Eseyin, Toluyemi, $\&$ O ni, 2016). Data dari BPS (2017) menunjukkan bahwa tingkat kemiskinan di Provinsi Jawa Tengah sebesar 13,19\% lebih tinggi dibanding tingkat kemiskinan nasional sebesar 10,70\%. Bahkan bila dibandingkan dengan provinsi-provinsi lain di Pulau Jawa, Jawa Tengah memiliki tingkat kemiskinan tertinggi pada tahun 2016 di semester kedua. Tentu saja hal ini perlu menjadi perhatian pemerintah mengingat sektor pertanian yang identik dengan kemiskinan yangsampai saat ini masih membelenggu Provinsi Jawa Tengah. U ntuk itu, pembangunan sektor pertanian harus memiliki strategi dan kebijakan yang tepat agar mampu mengangkat sektor pertanian dalam pertumbuhan maupun pembangunan ekonomi.

Dalam pembangunan ekonomi, terdapat hubungan antarsektor perekonomian yang saling berkaitan. Secara agregat sektor pertanian berperan dalam proses pembangunan industri karena sebagian input sektor industri berasal dari output sektor pertanian. Semakin banyak produksi sektor industri maka semakin banyak pula output produksi sektor pertanian, begitu pula dengan sektor lain. Selain itu input sektor pertanian juga berasal dari output sektor-sektor lain seperti sektor industri. Semakin meningkat output sektor pertanian maka akan meningkatkan input sektor pertanian yang berasal dari sektor lain. $\mathrm{H}$ al inilah yang disebut dengan keterkaitan antar sektor dalam perekonomian.

Analisis keterkaitan antar sektor ini berawal dari hubungan antara sektor pertanian dan sektor industri dalam perekonomian (N azara, 2005). Dalam analisis keterkaitan antarsektor ini, terdapat dua macam indeks yaitu indeks daya penyebaran dan indeks derajat kepekaan. Kedua indeks ini mampu melihat sektor yang mampu merangsang 
pertumbuhan ekonomi dan memiliki kepekaan yang tinggi. Sektor yang memiliki nilai tambah tinggi belum tentu memiliki indeks daya penyebaran dan indeks derajat kepekaan yang tinggi. Sektor dengan nilai indeks daya penyebaran dan indeks derajat kepekaan yang tinggi merupakan sektor kunci bagi pembangunan ekonomi daerah.

Berbagai penelitian membahas peran sektor pertanian dalam pembangunan yang cukup menunjukkan hasil yang tinggi seperti di Riau (Khairunnas, Bakce \& Edwina, 2014), Jawa Timur (O ktavia, Hanani \& Suhartini, 2016), dan Banjarnegara (Fortunika, Istiyanti \& Sriyadi, 2017). Namun hasil tersebut belum secara rinci membahas seberapa besar dampak indeks daya penyebaran dan indeks derajat kepekaan sektor pertanian terhadap sektor-sektor perekonomian lain dalam rangka pembangunan ekonomi daerah. $\mathrm{H}$ al inilah yang melatarbelakangi penelitian ini untuk fokus membahas indeks daya penyebaran dan indeks derajat kepekaan pada sektor pertanian. Oleh karena itu, penelitian ini bertujuan untuk menganalisis daya penyebaran dan derajat kepekaan sektor pertanian dalam pembangunan ekonomi Provinsi Jawa Tengah.

Jawa Tengah merupakan provinsi yang cukup besar dalam mengandalkan sektor pertanian dalam pembangunan ekonomi daerah. Dengan demikian, penelitian ini dapat memberikan gambaran bagi pemerintah Provinsi Jawa Tengah dalam membuat kebijakan yang tepat untuk sektor pertanian dan sektor-sektor lain yang menjadi sektor kunci bagi perekonomian.

\section{METODE PENELITIAN}

Data yang digunakan dalam penelitian ini adalah data sekunder berupa Tabel Input 0 utput Provinsi Jawa Tengah tahun 2013, data PDRB Provinsi Jawa Tengah, dan data jumlah tenaga kerja Provinsi Jawa Tengah yang diperoleh dari BPS. Analisis data yang digunakan dalam penelitian ini adalah analisis input-output (IO ). Pada dasarnya, analisis input-output dapat melihat hubungan antar sektor dalam suatu perekonomian. Adanya keterkaitan antarsektor menimbulkan keseimbangan penawaran dan permintaan dalam perekonomian karena input suatu sektor merupakan output sektor lainnya begitu pula sebaliknya ( $N$ azara, 2005; W idodo, 2006). Dalam analisis keterkaitan antarsektor, terdapat dua macam keterkaitan yaitu keterkaitan ke belakang dan keterkaitan ke depan.

U ntuk melihat keterkaitan antar sektor perekonomian secara holistik, Rasmussen (1956) mengusulkan dua macam ukuran keterkaitan yaitu power of dispersion for backward link- age atau disebut indeks daya penyebaran dan sensitifity of dispersion for forward linkage atau indeks derajat kepekaan (Daryanto \& H afizrianda, 2013). Analisis daya penyebaran dan derajat kepekaan ini merupakan analisis yang sering digunakan dalam analisisinput-output. Pada dasarnya indeks daya penyebaran dan indeks derajat kepekaan ini adalah keterkaitan ke belakang dan keterkaitan ke depan. Namun bedanya dalam indeks daya penyebaran dan derajat kepekaan ini menyetarakan perbandingan dengan cara menormalisasi keterkaitan baik keterkaitan kebelakang maupun keterkaitan kedepan. Kedua indeksini dapat menunjukkan sektor kunci dalam pembangunan ekonomi dengan melihat nilai indeks daya penyebaran dan nilai indeks derajat kepekaan. Berikut penjelasan tentang indeks daya penyebaran dan derajat kepekaan:

\section{INDEKS DAYA PENYEBARAN}

Indeks daya penyebaran merupakan dampak perubahan permintaan akhir pada suatu sektor terhadap output secara agregat. Indeks daya penyebaran berasal dari nilai keterkaitan ke belakang total yang dinormalisasi dengan membagi ratarata matriks kebalikan Leontief. D engan kata lain, jumlah setiap kolom matrik kebalikan Leontief yang dinormalisasi dengan membagi nilai ratarata jumlah matrik kebalikan Leontief itu sendiri (M atsuoka, 2017; Nazara, 2005; H umavindu \& Stage, 2013). Pembagian dengan rata-rata matrik kebalikan Leontief merupakan normalisasi dari keterkaitan kebelakang total tersebut agar menjadi perbandingan perekonomian yangsetara. Rumus indeks daya penyebaran (M iller \& Blair, 2009) adalah:

$$
B L_{j}=\frac{\sum_{i=1}^{n} \alpha_{i j}}{\frac{1}{n} \sum_{i=1}^{n} \quad \sum_{j=1}^{n} \alpha_{i j}}
$$

Dimana $\mathrm{BL}_{\mathrm{i}}=$ indeks daya penyebaran, $\mathrm{n}=$ jumlah sektor, dan $\alpha_{i j}=$ koefisien kebalikan Leontief (I-A $)^{-1}$ (kolom). Suatu sektor dengan nilai indeks daya penyebaran lebih dari satu $\left(B L_{i}>1\right)$ menunjukkan secara relatif permintaan akhir suatu sektor dalam memacu pertumbuhan produksi lebih besar dari rata-rata. Dengan begitu sektor tersebut menjadi sektor strategis dalam memacu pertumbuhan ekonomi, begitu pula bila sebaliknya.

\section{INDEKS DERAJ AT KEPEKAAN}

Indeks derajat kepekaan merupakan dampak yang terjadi pada output suatu sektor sebagai akibat perubahan permintaan akhir pada masingmasing sektor perekonomian. Indeks derajat kepekaan berasal dari keterkaitan ke depan 
total yang dinormalisasi dengan membagi jumlah rata-rata keterkaitan kedepan dengan membagi rata-rata matrik kebalikan Leontief. $\mathrm{H}$ al ini dapat dikatakan bahwa jumlah setiap baris matrik kebalikan Leontief yang dinormalisasi dengan membagi nilai rata-rata jumlah matriks kebalikan Leontief itu sendiri. Normalisasi tersebut ditujukan agar perbandingan perekonomian menjadi setara. Rumusindeks derajat kepekaan (M iller \& Blair, 2009) adalah:

$$
\mathrm{FL}_{i}=\frac{\sum_{i=1}^{\mathrm{n}} \mathrm{b}_{\mathrm{ij}}}{\frac{1}{n} \sum_{i=1}^{\mathrm{n}} \sum_{j=1}^{n} \mathrm{~b}_{\mathrm{ij}}}
$$

D imana $\mathrm{FL}_{\mathrm{i}}=$ indeks derajat kepekaan, $\mathrm{n}=$ jumlah sektor, dan $b_{i j}=$ matriks kebalikan Leontief $(I-A)^{-1}$ (baris). Suatu sektor dengan indeks derajat kepekaan lebih dari satu $\left(\mathrm{FL}_{i}>1\right)$ menunjukkan bahwa secara relatif dapat memenuhi permintaan akhir diataskemampuan ratarata sektor lainnya. M aka sektor tersebut dapat disebut sebagai sektor strategis, begitu pula dengan sebaliknya.

\section{TABH 1 PENOLASHKASAN15GKIORTABHINPUFOIIPUTFOMNB JAMATENAH}

\begin{tabular}{|c|c|c|}
\hline $\begin{array}{l}\text { Koce } \\
\text { Settor }\end{array}$ & $\begin{array}{l}\text { Ageged } \\
\text { Sttor }\end{array}$ & Setta \\
\hline 1 & $1-4$ & TanenanPangr \\
\hline 2 & $5-11$ & Tanemanlbtikuture \\
\hline$\Xi$ & $12-2$ & TanatanPeklarer \\
\hline 4 & $\overline{z-\Sigma}$ & Peterikr \\
\hline 5 & $24-2$ & Kentanen\&PedongenKay \\
\hline$\epsilon$ & $26-2 i$ & Peilenar \\
\hline 7 & $\mathcal{\varepsilon}$ & JasaPatariar \\
\hline$\varepsilon$ & 飞-3] & Petantrangan\&Galia \\
\hline$\underline{\mathrm{C}}$ & $32-66$ & Indstí Pengdaher \\
\hline $1 C$ & б- & Pergackanlistrik Cas \&Ai \\
\hline 11 & $\Subset-\pi$ & Kantuks \\
\hline $\bar{\Sigma}$ & 71-T & 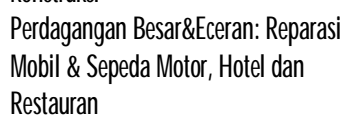 \\
\hline 巨 & $74-\pi$ & PergangktanSKonerikad \\
\hline 14 & $8-8$ & $\begin{array}{l}\text { Jasakerngan Peal Estdecanjasa } \\
\text { Peusdrean }\end{array}$ \\
\hline 15 & $8=-8$ & Jळ-Jळ \\
\hline
\end{tabular}

D alam analisis indeks daya penyebaran dan indeks derajat kepekaan, peneliti mengagregasi 88 sektor perekonomian menjadi 15 sektor perekonomian (Tabel 1). O leh karena itu, penelitian ini memfokuskan pada sektor pertanian dengan men gagregasi sektor pertanian menjadi 7 sektor yaitu sektor tanaman pangan, sektor hortikultura, sektor perkebunan, sektor peternakan, sektor kehutanan dan penebangan kayu, sektor perikanan dan terakhir sektor jasa pertanian.

Pengagregasian sektor perekonomian ini dilakukan untuk memudahkan dalam mengkategorikan sektor-sektor perekonomian menjadi lebih ringkas. Setelah mengagregasi sektor-sektor perekonomian kemudian menganalisis dampak penyebaran dengan indeks daya penyebaran dan indeks derajat kepekaan. Analisis ini mampu menunjukkan bagaimana pertumbuhan suatu sektor dalam mempengaruhi ataupun dipengaruhi oleh pertumbuhan sektor-sektor lainnya.

\section{SEKTOR PRIORITAS}

Penentuan sektor prioritas dapat dilihat dari nilai indeks penyebaran dan indeks derajat kepekaan. Bila suatu sektor memiliki nilai indeks daya penyebaran dan indeks derajat kepekaan tinggi maka sektor tersebut dikategorikan sebagai sektor kunci atau sektor prioritas dalam perekonomian. Terdapat beberapa kriteria peringkat sektor prioritas yang dapat dirinci sebagai berikut (W idodo, 2006):

\section{TA田2 KRTIRAPENNIUANPARNOAAGKCRPACRTAS}

\begin{tabular}{|c|c|c|}
\hline $\begin{array}{l}\text { IndtkLaya } \\
\text { Penderan }\end{array}$ & $\begin{array}{l}\text { Irraks Drajt } \\
\text { Keaken }\end{array}$ & Pioita \\
\hline Tingg (>1) & $\operatorname{Tingg}(>1)$ & 1 \\
\hline Tingg (>1) & Pendh $(<1)$ & ॥ \\
\hline Pecth $(<1)$ & $\operatorname{Tingg}(>1)$ & III \\
\hline Pecth $(<1)$ & Perdah $(<1)$ & N \\
\hline
\end{tabular}

Berdasarkan Tabel 2, terdapat empat kriteria dalam penentuan peringat sektor prioritas suatu wilayah. Sektor yang memiliki indeks daya penyebaran dan indeks derajat kepekaan tinggi merupakan sektor prioritas I atau dapat disebut sebagai sektor kunci dalam pembangunan ekonomi. Sektor prioritas II yaitu sektor dengan indeks daya penyebaran tinggi tetapi indeks derajat kepekaannya rendah. Sektor prioritas II dapat disebut dengan sektor strategis atau sektor potensial. Pada sektor prioritas III, nilai indeks daya penyebarannya rendah namun indeks derajat kepekaan tinggi. Sektor-sektor yang termasuk dalam sektor III dapat dikategorikan sebagai sektor strategisatau sektor potensial. Peringkat terakhir dalam sektor prioritas yaitu sektor prioritas IV, sektor ini memiliki indeks daya penyebaran dan derajat kepekaan yang rendah yang disebut sektor tertinggal.

\section{HASIL DAN PEMBAHASAN DAYA PENYEBARAN PADA PEREKONOMIAN DI PROVINSI I AWA TENGAH}

Daya penyebaran menggambarkan kekuatan suatu sektor dalam merangsang pertumbuhan output sektor-sektor perekonomian lainnya sehingga memacu pertumbuhan 
ekonomi. Hasil analisis menunjukkan bahwa indeks daya penyebaran di Provinsi Jawa Tengah dengan nilai indekslebih dari 1 adalah sektor peternakan, sektor industri pengolahan, sektor pengadaan listrik, gas dan air, sektor konstruksi, sektor perdagangan besar dan kecil: reparasi mobil dan sepeda motor, hotel dan restauran, sektor pengangkutan dan komunikasi serta sektor jasa-jasa (Tabel 3). Sektor-sektor dengan nilai indeks lebih dari 1 tersebut menggambarkan bahwa sektor tersebut memiliki daya dorong yang kuat dibandingkan dengan sektor lain yangmemiliki nilai indeks daya penyebaran kurang dari satu.

\section{TABH 3 INDASDAAPENMABANPADAPEAONOMAND PROINB JANATENCAH}

\begin{tabular}{|c|c|c|c|}
\hline $\mathrm{Nb}$ & Settor & $\begin{array}{l}\text { IndasLbya } \\
\text { Penyebran }\end{array}$ & Rarking \\
\hline 1 & TaranmPangr & 0,815 & 1 \\
\hline 2 & Taramanlatikuture & $0, \pi T$ & 15 \\
\hline$\Xi$ & TarandenPekdarer & $0,8 / 5$ & $\underline{\mathrm{C}}$ \\
\hline 4 & Peterika & 1,096 & 5 \\
\hline 5 & $\begin{array}{l}\text { Kefutanen\&Perdengan } \\
\text { Kayu }\end{array}$ & 0,799 & 14 \\
\hline$\epsilon$ & Peilana & $0,85=$ & 11 \\
\hline 7 & JasaPetaria & 0,917 & $\varepsilon$ \\
\hline$\varepsilon$ & Petantangen\&Galiar & $0,82=$ & 12 \\
\hline$\underline{c}$ & Indstri Pengdater & $1,22 x$ & $\Xi$ \\
\hline $1 C$ & Pergacbanlistik, Gas\&Ai & 1,332 & 2 \\
\hline 11 & $\begin{array}{l}\text { Kantrus } \\
\text { Peackgangen Besar can }\end{array}$ & $1,35=$ & 1 \\
\hline 12 & 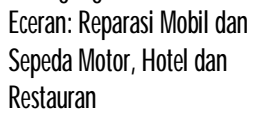 & 1,027 & 7 \\
\hline 1 & PergengktanSKonerikad & 1,27 & 4 \\
\hline 14 & 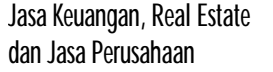 & 0,850 & 10 \\
\hline 15 & 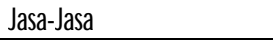 & 1,076 & $\epsilon$ \\
\hline
\end{tabular}

Sektor dengan nilai indeks daya penyebaran terbesar di Provinsi Jawa Tengah adal ah sektor konstruksi $(1,353)$, artinya sektor konstruksi merupakan sektor yang memiliki kekuatan terbesar dalam memacu pertumbuhan produksi seluruh sektor di Provinsi Jawa Tengah. $\mathrm{H}$ al tersebut selaras dengan penelitian Zuhdi (2017) bahwa indeks daya penyebaran melihat kekuatan suatu sektor dalam mempengaruhi seluruh sektor. Sektor pertanian memiliki nilai indekslebih dari satu yaitu sektor peternakan $(1,096)$, artinya sektor peternakan mampu merangsang pertumbuhan produksi lebih besar dari rata-rata, sehingga sektor ini dapat dikatego rikan dalam sektor strategis yang memacu pertumbuhan output. Sektor tanaman pangan, sektor hortikultura, sektor perkebunan, sektor kehutanan dan penebangan kayu, sektor perikanan serta sektor jasa perikanan memiliki nilai indeks daya penyebaran kurang dari satu. $\mathrm{H}$ al ini menunjukkan bahwa sektor-sektor tersebut belum mampu mendorong pertumbuhan produksi pada semua sektor perkonomian di Provinsi Jawa Tengah.

Indeks daya penyebaran pada sektor pertanian secara keseluruhan belum mampu memacu pertumbuhan produksi pada semua sektor perekonomian kecuali sektor peternakan. $\mathrm{H}$ al ini juga didukung oleh penelitian Zaini (2004) bahwa sektor peternakan memiliki indeks daya penyebaran di atas rata-rata. Sektor peternakan mampu mendorong pertumbuhan produksi secara agregat karena dalam sektor peternakan memiliki keterkaitan ke belakang yang erat dengan banyak sektor. O utput pada sektor peternakan membutuhkan input-input dari sektor-sektor lain seperti pakan ternak, alat-alat dan mesin peternak, obat-obatan dan vaksin ternak. Tentu saja jika output sektor peternakan meningkat, input produksi dari berbagai sektor juga akan meningkat. $\mathrm{H}$ al ini juga berkaitan dengan permintaan pada sektor peternakan yang cukup tinggi bila dibandingkan dengan sektor pertanian lainnya.

M enurut BPS (2013), komponen konsumsi rumah tangga dalam tabel input-output Provinsi Jawa Tengah pada sektor peternakan memiliki nilai tertinggi diantara komponen permintaan akhir lainnya. Bahkan jika dibandingkan dengan semua konsumsi pada sektor pertanian lainnya, nilai konsumsi pada sektor peternakan menempati urutan teratas. $\mathrm{H}$ al ini selaras dengan penelitian sebelumnya (Zuhdi, Putranto \& Prasetyo, 2014) bahwa sektor peternakan di masa yang akan datang memiliki implikasi terbesar yang berasal dari konsumsi rumah tangga. D engan demikian dapat dikatakan bahwa sektor peternakan dapat dikategorikan sebagai sektor strategis dalam perekonomian di Provinsi Jawa Tengah mewakili sektor pertanian secara keseluruhan.

\section{DERAJ AT KEPEKAAN PADA PEREKONOMIAN DI PROVINSI JAWA TENGAH}

Indeks derajat kepekaan menggambarkan dampak relatif yang ditimbulkan karena pengaruh eksternal suatu sektor berimbas pada sektor-sektor lain yang ada di hilir. Indeks derajat kepekaan dapat digunakan untuk menganalisis kepekaan sektor tertentu terhadap pengaruh eksternal (Zuhdi, 2017). Bila suatu sektor memiliki nilai indeks derajat kepekaan tinggi, sektor tersebut memiliki kepekaan lebih terhadap pengaruh eksternal. Sektor perekonomian di Provinsi Jawa Tengah yang memiliki nilai indeks derajat kepekaan lebih dari 1 adalah sektor pertambangan dan galian, 
sektor industri pengolahan serta sektor perdagangan besar dan eceran: reparasi mobil dan sepeda motor, hotel dan restauran (Tabel 4). Ketiga sektor tersebut memiliki nilai indeks di atas ratarata karena sektor-sektor tersebut memiliki output produksi yang banyak digunakan oleh sektor-sektor perekonomian lainnya. D engan kata lain sektor-sektor tersebut memiliki keterkaitan ke depan dengan industri hilir yang panjang.

Sektor terbesar dalam indeks derajat kepekaan pada perekonomian di Provinsi Jawa Tengah adalah industri pengolahan $(2,840)$. Sektor indutri pengolahan terbukti menjadi sektor dengan kepekaan yang tinggi pada seluruh sektor hilir yang dipengaruhi oleh perubahan aspek eksternal. Ketika terjadi perubahan aspek eksternal seperti pada permintaan akhir sektor industri pengolahan maka akan berdampak pada sektor industri pengolahan sendiri dan juga sektor-sektor lain yang memiliki keterkaitan dengan sektor tersebut. $\mathrm{H}$ al ini menunjukkan bahwa sektor industri pengolahan berperan penting dalam pengembangan sektor perekonomian lainnya secara keseluruhan.

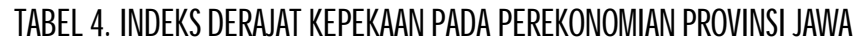 TENAH}

\begin{tabular}{|c|c|c|c|}
\hline $\mathrm{N}$ & Satka & $\begin{array}{l}\text { IndasLrajt } \\
\text { Keptean }\end{array}$ & Pakkin \\
\hline$\overline{1}$ & TaramanPangr & 0,955 & $\epsilon$ \\
\hline 2 & TanananHbtikiture & 0,70 & 11 \\
\hline$\Xi$ & TanandnPekdarer & 0,75 & G \\
\hline 4 & Peternar & 0,66 & 五 \\
\hline 5 & $\begin{array}{l}\text { Kefutanens } \\
\text { Pendengenkayu }\end{array}$ & 0,655 & 1 \\
\hline$\epsilon$ & Peilanar & $0,64 C$ & $1<$ \\
\hline 7 & JasaPetaria & 0,61 & 15 \\
\hline$\varepsilon$ & Patantangen\&Gêtia & 1,534 & 2 \\
\hline$\underline{\mathbf{S}}$ & Indstri Pengdaher & $2,84 C$ & 1 \\
\hline $1 C$ & $\begin{array}{l}\text { Pergackanlistrik, Gas } \\
\text { \&Air }\end{array}$ & $0,75 C$ & $1 C$ \\
\hline 11 & Kontukj & 0,80 & $\varepsilon$ \\
\hline 立 & 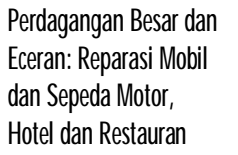 & $1,26=$ & $\Xi$ \\
\hline 1 & $\begin{array}{l}\text { Pengengktanskoneri } \\
\text { kai }\end{array}$ & 0,991 & 4 \\
\hline 14 & $\begin{array}{l}\text { Jasakeangan Ped } \\
\text { Estedanjas } \\
\text { Peusdran }\end{array}$ & $0,97 \varepsilon$ & 5 \\
\hline 15 & Jæ-Jळ & $0,86=$ & 7 \\
\hline
\end{tabular}

Sektor pertanian secara keseluruhan memiliki nilai indeks derajat kepekaan yang rendah. $\mathrm{H}$ al ini mengindikasikan bahwa sektor pertanian di Provinsi Jawa Tengah memiliki kepekaan yang rendah terhadap perubahan aspek eksternal, sehingga keterkaitan ke depan antar sektor hilir juga rendah. Kepekaan yang rendah pada sektor pertanian dikarenakan output sektor pertanian masih banyak yang langsung dikonsumsi. Artinya sektor pertanian memiliki rantai keterkaitan ke depan yanglebih pendek dibandingkan dengan sektor-sektor yang memiliki indeks derajat kepekaan di atas nilai satu. N ilai indeks derajat kepekaan tertinggi pada sektor pertanian secara keseluruhan adalah sektor tanaman pangan sebesar 0,955. Nilai tersebut menunjukkan bahwa sektor tanaman pangan memiliki kepekaan tertinggi dibandingkan dengan sektor pertanian secara keseluruhan, walaupun bila dilihat secara nyata berada dibawah nilai ratarata keseluruhan indeks. $\mathrm{H}$ al ini sedikit berbeda dengan pen elitian sebelumnya (Septiadi, Pinilih \& Shaferi, 2017), bahwa sektor pertanian tidak seluruhnya memiliki indeks derajat kepekaan yang rendah, di mana sektor padi dan tanaman bahan makanan lainnya memiliki indeks lebih dari satu. Perbedaan tersebut dapat terjadi karena pengagregasian sektor yang berbeda sehingga akan menghasilkan hasil analisisyang berbeda pula.

SEKTOR PRIORITAS DALAM PEMBANGUNAN EKONOMI DI PROVINSI J AWA TENGAH

Sektor prioritas I dalam pembangunan ekonomi di Provinsi Jawa Tengah adalah sektor industri pengolahan dan sektor perdagangan besar dan eceran: reparasi mobil dan sepeda motor, hotel dan restauran (Tabel 5). Kedua sektor tersebut mempunyai nilai indeks daya penyebaran dan daya kepekaan yang tinggi. A rtinya, kedua sektor tersebut memiliki dampak penyebaran pada sektor hulu atau sektor input produksi dan output keduanya menjadi input sektor lain atau sektor hilir. Jika terjadi gejolak yang mempengaruhi sektor prioritas maka berdampak cukup signifikan bagi perekonomian secara agregat terutama sektor-sektor yang memiliki keterkaitan yang tinggi (Soedomo, 2010). Begitu pula bila terdapat stimulus pada sektor prioritas, maka berdampak pada peningkatan pertumbuhan yang lebih besar tehadap sektor-sektor perekonomian lainnya.

Sektor yang termasuk dalam prioritas II yaitu sektor peternakan, sektor pengadaan listrik, gas dan air, sektor kontruksi, sektor pengangkutan dan komunikasi serta sektor jasa-jasa. Sektor-sektor tersebut mampu memacu pertumbuhan sektor input atau hulu dan juga menunjukkan bahwa sektor-sektor tersebut memiliki rantai keterkaitan yang pendek atau sektor lebih hilir yang lebih dekat dengan konsumen. Seperti sektor peternakan, sebagian besar outputnya menjadi konsumsi langsung setiap hari. Begitu pula 
sektor konstruksi, sektor ini juga merupakan sektor yang lebih dekat dengan konsumen (Sjafrizal, 2008). Terlebih sektor listrik, gas dan air yang menyangkut kebutuhan publik yang banyak menjadi input sektor industri yang berperan penting dalam perekonomian. Oleh karena itu, sektor tersebut menjadi sektor yang dikelola oleh pemerintah langsung, sehingga lebih terkontrol dalam pengelolaan maupun pengawasannya. $\mathrm{H}$ al ini menunjukkan bahwa sektor prioritas II lebih dekat dengan sektor hilir atau berhubungan dengan konsumen langsung. Dengan demikian, sektor-sektor yang termasuk dalam prioritas II setelah sektor prioritas I juga menjadi perhatian pemerintah dalam pembangunan ekonomi.

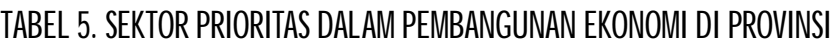 JAMATENOH}

\begin{tabular}{|c|c|c|}
\hline \multicolumn{3}{|c|}{ IndAscbajđkedkr } \\
\hline & Pendh $(<1)$ & Tingg (>1) \\
\hline Tinggi (>1) & 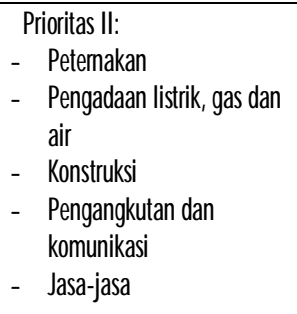 & 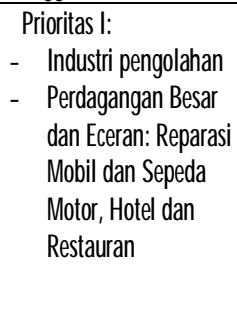 \\
\hline $\tan \overline{\operatorname{Pendh}(<1)}$ & 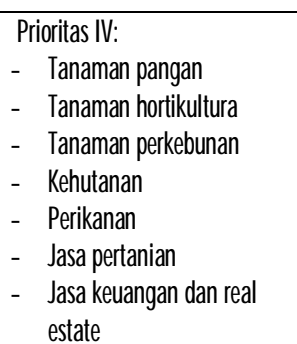 & $\begin{array}{l}\text { Pioitaslll: } \\
\text { - Petantbengencen } \\
\text { gdian }\end{array}$ \\
\hline
\end{tabular}

Sektor pertambangan dan galian merupakan sektor prioritas III dengan nilai indeks daya penyebaran rendah namun memiliki indeks derajat kepekaan yang tinggi. $\mathrm{Hal}$ ini menunjukkan bahwa sektor tersebut belum mampu memacu pertumbuhan produksi sektor-sektor inputnya, namun memiliki kepekaan yang tinggi terhadap perubahan eksternal pada sektor-sektor hilirnya.

Sektor dengan prioritas IV atau prioritas terakhir yaitu sektor yang memiliki nilai indeks daya penyebaran dan indeks derajat kepekaan yang rendah. Sektor yang termasuk dalam ketegori prioritas IV adalah sektor tanaman pangan, sektor tanaman hortikultura, sektor tanaman perkebunan, sektor kehutanan, sektor perikanan, sektor jasa pertanian dan sektor jasa keuangan dan real estate. Sektor-sektor tersebut tidak bisa diandalkan dalam merangsang pertumbuhan produksi sektor-sektor lain dan juga memiliki kepekaan yang rendah terhadap perubahan pada sektor-sektor hilirnya.

Berdasarkan pengelompokan sektor prioritas dalam pembangunan ekonomi, sektor pertanian secara keseluruhan tidak termasuk dalam sektor prioritas I. Sektor pertanian yang diwakili oleh subsektor peternakan mampu menjadi sektor prioritas II dalam pembangunan ekonomi di Provinsi Jawa Tengah. Walaupun menduduki prioritas II, sektor peternakan mampu mendorong pertumbuhan produksi sektor perekonomian secara agregat. $\mathrm{H}$ al ini dikarenakan subsektor peternakan merupakan sektor yang memiliki rantai keterkaitan sektor lebih pendek sehingga lebih dekat dengan konsumen atau masyarakat. $\mathrm{Hal}$ ini menunjukkan bahwa subsektor peternakan menjadi subsektor kunci pada sektor pertanian di Jawa Tengah.

$\mathrm{H}$ al-hal yang berkaitan langsung dengan masyarakat akan menjadi perhatian khusus bagi pemerintah Provinsi Jawa Tengah dalam merumuskan kebijakan yang tepat untuk pembangunan ekonomi secara menyeluruh khususnya sektor pertanian yang banyak menyerap tenaga kerja. Selain itu perumusan kebijakan yang tepat juga dapat meningkatkan perekonomian yang berdampak pada peningkatan kesejahteraan penduduk sehingga mampu mengurangi kemiskinan. D engan demikian, diharapkan hasil penelitian ini dapat memberikan gambaran pada pemerintah Provinsi Jawa Tengah mengenai bahan pertimbangan dalam mengambil kebijakan yangtepat bagi pembangunan ekonomi daerah yang tepat dan merata.

\section{KESIMPULAN}

Potensi sektor pertanian secara keseluruhan pada pembangunan ekonomi Provinsi Jawa Tengah ditunjukkan dengan masukknya sektor peternakan dalam sektor prioritas II (strategis) yang dilihat dari indeks daya penyebaran yang tinggi namun indeks derajat kepekaan yang rendah. Walaupun sektor pertanian bukan menjadi sektor prioritas I (kunci) dalam pembangunan ekonomi secara keseluruhan, namun indeks daya penyebaran yang tinggi pada sektor peternakan terbukti memberikan stimulus yang besar dalam pertumbuhan produksi sektor hulu. Pertumbuhan tersebut mendorong sektor lain tumbuh, menyerap tenaga kerja dan meningkatkan pendapatan masyarakat khusu snya pada sektor pertanian. 


\section{DAFTAR PUSTAKA}

Arsyad, L. (2011). Pengantar Perencanaan Pembangunan Ekonomi Daerah. Yogyakarta: BPFE.

BPS. (2013). Tabel Input Output Jawa Tengah 2013. Retrieved from https:/ / jateng.bps.go.id/publication/2015/02/04/ $191 \mathrm{f37fd0fed78856693ef4e/tabel-input-output-jawa-tengah-}$ 2013.html

BPS. (2017). PDRB Jawa Tengah Atas Dasar Harga Konstan 2010 Menurut Lapangan Usaha (Juta Rupiah), 2010 - 2016. Retrieved from https:// jateng.bps.go.id/statictable/2017/11/06/1683/-seri-2010-pdrb-jawatengah-atas-dasar-harga-konstan-2010-menurut-lapangan-usahajuta-rupiah-2010-2016.html

BPS. (2017). Penduduk Berumur 15 tahun Keatas yang Bekerja Selama Seminggu yang Lalu Menurut Lapangan Pekerjaan Utama dan Jenis Kelamin di Provinsi Jawa Tengah, 2007-2016. Retrieved from https:// jateng.bps.go.id/statictable/2017/03/22/1479/penduduk-berumur-15tahun-ke-atas-yang-bekerja-selama-seming gu-yang-lalu-menurutlapangan-pekerjaan-utama-dan-jenis-kelamin-di-provinsi-jawatengah-2007-2016.html

BPS. (2017). Persentase penduduk Miskin Menurut Provinsi 2007-2017. Retrieved from https://www.bps.go.id/linkTableDinamis/view/id/1219

Cuong, N. V. (2010). Does Agriculture Help Poverty and Inequality Reduction? Evidence from Vietnam. Agricultural Economics Review, 11(1), 44-56. https://EconPapers.repec.org/RePEc:ags:aergaa:118576

Dariah, A. R., \& Sundaya, Y. (2012). Pengaruh Perkembangan Sektor Perdagangan, Hotel dan Restoran Kota Bandung terhadap Sektor Pertanian Daerah Lainnya di Jawa Barat. Jurnal Ekonomi Kuantitatif Terapan, 5(2), 79-150. https://ojs.unud.ac.id/index.php/jekt/article/ view $/ 2055$

Daryanto, A., \& Hafizrianda, Y. (2013). Analisis Input-Output \& Social Accounting Matrix Untuk Pembangunan Ekonomi Daerah. Bogor: IPB Press.

Eseyin, O., Toluyemi, S. T., \& Oni, O. O. (2016). Investment in Agricultural Sector: Implication for Poverty Reduction in Nigeria (1985-2012). American Journal of Business and Society, 1(3), 118-128. http:// files.aiscience.org/journal/article/pdf/70590014.pdf

Fortunika, S. O., Istiyanti, E., \& Sriyadi. (2017). Kontribusi Sektor Pertanian terhadap Perekonomian Kabupaten Banjarnegara, Provinsi Jawa Tengah (Analisis Struktur Input-Output). Jurnal Agraris: Journal of Agribusiness and Rural Development Research, 3(2), 119-127. http:/ /dx.doi.org/10.18196/agr.3252

Humavindu, M. N., \& Stage, J. (2013). Key Sectors of The Namibian Economy. Journal of Economics Structures, 2(1), 1-15. https:// link.springer.com/article/10.1186/2193-2409-2-1.

Izuchukwu, O. O. (2011). Analysis of The Contribution of Agricultural Sector on The Nigerian Economic Development. World Review of Business Reasearch, 1(1), 191-200. http://wrbrpapers.com/static/documents/ March/2011/15.\%200ji-Okoro-FINAL.pdf.

Jhingan, M. L., (2010). Ekonomi Pembangunan dan Perencanaan. Jakarta: PT. Rajagrafindo Persada.

Khairunnas., Bakce, D., \& Edwina, S. (2014). Analisis Sektor Kunci dalam Perekonomian Provinsi Riau: Analisis Input-Output. Indonesian Journal of Agricultural Economics, 5(2), 47-66. https://ejournal.unri.ac.id/ index.php/lJAE/article/view/3446

Kuncoro, M. (2010). Masalah, Kebijakan \& Politik Ekonomika Pembangunan. Jakarta:

Penerbit Erlangga.

Matsuoka, H. (2017). An Analysis of Japanese Industrial Structure Using Input-Output Table. Journal of Engeneering and Applied Sciences, 12(4), 974-980. http:// http://docsdrive.com/pdfs/medwelljournals/ jeasci/2017/974-980.pdf

Miller, R. E., \& Blair, P. D. (2009). Input-Output Analysis, Foundations and Extensions. Inggris: Cambridge University Press.

Nazara, S. (2005). Analisis Input Output. Jakarta: Lembaga Penerbit Fakultas Ekonomi UI.

Oktavia, H. F., Hanani, N., \& Suhartini. (2016). Peran Sektor Pertanian dalam Pembangunan Ekonomi di Provinsi Jawa Timur (Pendekatan Input-Output). Jurnal Habitat, 27(2), 72-84. https://doi.org/10.21776/ ub.habitat.2016.027.2.9.

Omorogiuwa, O., Zivkovic, J., \& Ademoh, F. (2014). The Role of Agriculture In The Economic Development of Nigeria. European Scientific Journal, 10(4), 133-147. https://eujournal.org/index.php/esj/article/ download/2687/2539.

Rasmussen, P. N. (1956). Studies in Intersectoral Relations. Amsterdam: North-Holland PC.

Septiadi, A. D., Pinilih, M., \& Shaferi, I. (2017). Analisis Daya Penyebaran dan Derajat Kepekaan Sektor Ekonomi di Jawa Tengah. Jurnal Pro bisnis, 10(2), 38-47. http://ejournal.amikompurwokerto.ac.id/ index.php/probisnis/article/view/564

Sjafrizal. (2008). Ekonomi Regional: Teori dan Aplikasi. Padang: Penerbit Baduose Media.

Soedomo, R. P. (2010). Analisis Keterkaitan Antar Industri dan Sektor Kunci di Indonesia. Kajian ekonomi dan keuangan, 14(3), 101-115. http:// www.fiskal.kemenkeu.go.id/ojs_bkf/index.php/kek/article/view/71.

Tarigan, R. (2012). Ekonomi Regional: Teori dan Aplikasi. Jakarta: Bumi Aksara.

Todaro, M. (2006). Pembangunan Ekonomi Dunia Ketiga. Jakarta: Penerbit Erlangga.

Widodo, T. (2006). Perencanaan Pembangunan: Aplikasi Computer (Era Otonomi Daerah). Yogyakarta: UPP STIM YKPN.

Zaini, A. (2004). Daya Penyebaran Sektor Pertanian dalam Struktur Ekonomi Provinsi Kalimantan Timur: Pendekatan Input-Output. Jurnal Ekonomi Pertanian dan Pembangunan, 1(1), 8-12. http:// agb.faperta.unmul.ac.id/wp-content/uploads/2017/04/jurnal-vol-1no-1-zaini-.pdf.

Zuhdi, U., Putranto, N. A. R., \& Prasetyo, A. D. (2014). An Input-Output Approach To Know The Dynamics of Total Output of Livestick Sectors: The Case of Indonesia. Procedia Social and Behavioral Sciences, 109, 634-638. https://doi.org/10.1016/j.sbspro.2013.12.519.

Zuhdi, U. (2017). An Analysis of The Characteristics of Japanese Industrial Sectors from 2005 Through 2011. IOP Conference series: Earth and Environmental Science, 88, 1-6. https://doi:10.1088/1755-1315/88/ $1 / 012027$ 